\title{
Organizational learning in public organizations: an integrative review
}

\author{
Deriseđffa Doutoranda em Engenharia e Gestão do Conhecimento. Universidade Federal de Santa Catarina \\ (UFSC) - Brasil. denise cuffa@hotmail.com \\ AncheøVééiaSteil Doutora em Engenharia de Produção. Universidade Federal de Santa Catarina (UFSC) - Brasil. \\ anddreasteil@egc.ufsc.br
}

\begin{abstract}
This review analyzes the results of empirical studies on organizational learning (OL) in public organizations. We used integrative review method to research two international databases. By applying inclusion and exclusion criteria, twelve publications were selected for analysis. The results indicated that $\mathrm{OL}$ in public organizations is a relatively recent topic and little explored in empirical studies. Mostly consisting of qualitative studies, they describe $\mathrm{OL}$ with a focus on organizational changes and identify elements that inhibit (e.g., blame and caution) or facilitate (e.g., delegation of power, positive managerial coaching, active communication) the organizational learning process. In a smaller number, quantitative studies investigate $\mathrm{OL}$ antecedents such as knowledge acquisition and transformation and learning culture, and a consequent of $\mathrm{OL}$, organizational performance. This paper analyzes these results and suggests an agenda for organizational learning in public sector organizations.
\end{abstract}

Keywords: organizational learning; empirical studies; public sector organizations; integrative literature review.

\section{Aprendizagem organizacional em organizações públicas: uma revisão integrativa}

\section{RESUMO}

Esta revisão analisa os resultados de pesquisas empíricas sobre aprendizagem organizacional (AO) em organizações públicas. Foi utilizado o método de revisão integrativa para buscas em duas bases de dados internacionais. Após a aplicação de critérios de inclusão e exclusão, doze estudos foram selecionados para análise. Os resultados indicaram que $\mathrm{AO}$ em organizações públicas consiste em um tema relativamente recente e pouco explorado em estudos empíricos. Em sua maioria qualitativos, os estudos descrevem a AO a partir do foco em mudanças organizacionais e identificam elementos que inibem (culpa e cautela) ou facilitam (delegação de poder, coaching gerencial positivo, comunicação ativa, por exemplo) o processo de aprendizagem organizacional. Em menor quantidade, foram identificados estudos quantitativos, que investigam os antecedentes à $\mathrm{AO}$, como a aquisição e a transformação do conhecimento e a cultura de aprendizagem; e um consequente à $\mathrm{AO}, \mathrm{o}$ desempenho organizacional. $\mathrm{O}$ artigo analisa estes resultados e apresenta uma agenda de pesquisas para o construto.

Palavras: aprendizagem organizacional; estudos empíricos; organizações do setor público; revisão integrativa de literatura. 


\section{INTRODUCTION}

Public sector organizations have been pushed by society to learn, innovate and improve continuously their services (Hartley, 2008; Hartley and Skelcher, 2008). In the context of public management, organizational learning $(\mathrm{OL})$ is described as a strategy for organizations to perform their activities efficiently and effectively (Ferreira and Medeiros, 2011). For instance, learning processes in public organizations enable organizational self-correction as an adaptive mechanism to changes in their internal and external environment (Common, 2004). In spite of the expectations with the adoption of practices to induce organizational learning in public organizations, this is a complex task (Mahler and Casamayou, 2009) due to the bureaucratic nature of the public organizations (Yeo, 2007; Bastiani et al., 2015). Public organizations are part of a political environment and subject to high levels of scrutiny, accountability and formal political control (Hartley and Skelcher, 2008).

Studies indicate that the academic production on organizational learning in public context and public-sector learning process is still little expressive (Moynihan and Landuyt, 2009; Rashman et al., 2009; J ang, 2010; Easterby-Smith and Lyles, 2011; Maden, 2012; Olejarski et al., 2018). As pointed out by Jang (2010, p. 02), "despite the importance of organizational learning and the numerous studies conducted in private sector organizations during the past decades, (...) few empirical studies have been undertaken in the public sector".

A literature review on OL (Lyles and Easterby-Smith, 2003) showed that until the early 2000s, a small part (19\%) of the publications on OL analyzed the construct in public organizations. Reviews on OL in the public sector have focused on the relationship of OL with other constructs, such as knowledge management, both little explored in empirical research (Rashman et al., 2009; Easterby-Smith and Lyles, 2011). In the last 25 years, the interest on public organizations has increased (Rashman et al., 2009; Gilardi and Radaelli, 2012; Maden, 2012). An example is a recent study (Santos et al., 2015) that mapped scientific publications on $\mathrm{OL}$ and organizational memory and identified the need for studies that address these two constructs in public organizations. To contribute to the understanding of $\mathrm{OL}$ in public organizations from an approach based on evidence, this paper seeks to answer the following question: which are the results of empirical research on organizational learning in public organizations? Based on this question, the aim of this paper is to analyze the results of empirical studies on organizational learning in the public sector published in scientific journals.

This paper seeks to expand the understanding on what is known and what is not known on organizational learning in public organizations from an empirical perspective. The synthesis of empirical literature on this subject allows for the identification of gaps and the proposition of a research agenda. In practical terms, the access to accumulated empirical knowledge on $\mathrm{OL}$ in public organizations may be useful to the management of this kind of organization on federal, state and city levels (Antal et al., 2003).

\section{ORGANIZATIONAL LEARNING IN PUBLIC ORGANIZATIONS}

Organizational learning is a research area concerned about how organizations learn and how this can contribute to increasing their innovation and efficiency (Abel, 2015). In the context of public organizations, organizational learning is the creation and application of new knowledge to the political and innovation processes when implementing public policies (Common, 2004). This process permeates the knowledge society through the identification, generation, sharing, and interpretation of available knowledge (Rodríguez, 2005; Jensen, 2005; Santos, 2014) as well as through the coordination and preservation of knowledge that people already have (Jensen, 2005).

One consolidated perspective on organizational learning defines it as a process of change (cognitive and behavioral), which begins with individual learning, the interpretation and integration of this learning in the group level, and the institutionalization of such learning at the organizational level (Crossan et al., 2011). The result of this process is new organizational knowledge and routines, which influence new learning processes (Vera and Crossan, 2005). Organizational learning is thus a dynamic process through which individuals transfer their new ideas and actions to the group and the organization and, at the same time, what has already been learned by the organization influences groups and individuals (Crossan et al., 1999; Bapuji and Crossan, 2004; Crossan et al., 2011; Meral et al., 2014). "Organizational learning is an emergent property 
that depends not only on individual learning, but also on the pattern of interactions among the learning of all individual" (Avnet, 2015, p. 594). As pointed out by Picoli and Takahashi (2016), organizational learning occurs when, through its processes, new knowledge is incorporated into the organizational level.

The definition of $\mathrm{OL}$ as a process is aligned with a descriptive approach in as much as research on $\mathrm{OL}$ processes have "the objective of describing and understanding processes and behaviors" (Angeloni and Steil, 2011 , p. 125), based on scientific rigor. Research on OL ratifies group learning as a mediator of the relationship between individual and organizational learning (Edmondson et al., 2007), and OL as a basic process for the generation of organizational knowledge (Magalhães, 1998; Rashman et al., 2009; Moreno-Luzon and Lloria, 2008).

Public organizations play a crucial role in the country's competitiveness because they provide the necessary conditions and infrastructure that private companies need to be effective in national, regional and local levels (Hartley and Skelcher, 2008). Organizational learning is one of the most important ways that a public organization has to increase the creation and use of its knowledge (Whee et al., 2012). The study by Olejarski et al. (2018, p. 04) identified that organizational learning in public organizations can result from "culture, public-sector politics, and public performance holistically, as a process, within the context of the organization". Kasemsap (2017, p. 51) found that "organizational learning enables more effective responses to the dynamic environments". This study also identified that organizational learning contributes positively to the increased information sharing and communication. Other studies found a positive relationship between organizational learning and innovation capacity (Salim and Sulaiman, 2011) and intellectual capital (Naghi et al., 2010). Thus, learning within and between public organizations has been considered a key element for the improvement of public services (Rashman et al., 2009; J ang, 2010; Kasemsap, 2017). From this perspective, this paper emphasizes the learning process at the organizational level.

\section{METHOD}

This is an integrative review that seeks to "review, critique and synthesize representative literature" (Torraco, 2005, p. 356) on organizational learning in the public sector. We used the stages proposed by Cooper (1982) to carry out an integrative review: (i) problem formulation; (ii) data collection; (iii) data evaluation; (iv) analysis and interpretation; and (v) public presentation stage.

\subsection{Data collection}

We searched for papers on Scientific Electronic Library Online (Scielo), Scopus and on all databases indexed on ISI-Web of knowledge (Web of Science ${ }^{\mathrm{TM}}$ Core Collection; Derwent Innovations Index ${ }^{\mathrm{SM}}$; Korean databases of Korean periodicals - KCl); Russian Science Citation Index; Scielo Citation Index). These databases are representative of the scientific community and index important, multi-disciplinary, national and international scientific publications (Woszezenki et al., 2012).

The search words were "organi?ational learning", "public organi?ation", "public administration", "public sector", "public agency", "public management", in the search box ${ }^{1}$ of each database. We conducted the searches in pairs: "organi?ational learning" AND "public organi?ation"; "organi?ational learning" AND "public administration"; "organi?ational learning" AND "public sector"; "organi?ational learning" AND "public agency"; and "organi?ational learning" AND "public management". We used the "?" character for retrieving variations in the searched words. The search period corresponded to the available years on the databases, until December 31,2017 . This systematic search resulted in 451 papers (Table 01).

\footnotetext{
${ }^{1}$ ISI - Web of Knowledge (Search field: topic - title, abstract, keyword)

Scopus (Search field: article, title, abstract, keyword)

Scielo (Search field: all indexes)
} 


\begin{tabular}{lccc}
\hline \multicolumn{1}{c}{ Keywords } & $\begin{array}{c}\text { ISI - Web of } \\
\text { Science }\end{array}$ & Scopus & Scielo \\
\hline "organizational learning" AND "public organization" & 15 & 43 & 17 \\
"organizational learning" AND "public administration" & 35 & 38 & 07 \\
"organizational learning" AND "public sector" & 83 & 108 & 10 \\
"organizational learning" AND "public agency" & 02 & 17 & 02 \\
"organizational learning" AND "public management" & 21 & 25 & 28 \\
\hline Total of publications & $\mathbf{1 5 6}$ & $\mathbf{2 3 1}$ & $\mathbf{6 4}$ \\
\hline
\end{tabular}

Table 01. Keywords used to search on databases and the respective number of papers retrieved Search: Authors (2018)

We imported all papers into references management software, which automatically identified 232 duplicated papers, which were excluded. We then applied inclusion and exclusion critera to the 219 remaining papers.

\subsection{Data evaluation}

The application of the criteria (of inclusion and exclusion) occurred from the reading of the title and abstract of papers. When necessary, the paper was read in full.

Of the 219 articles, 207 were excluded on the basis of the following exclusion criteria: a) papers examining organizational learning from a prescriptive approach, which excluded 26 articles; b) gray literature such as books chapters and technical reports, theoretical papers, and empirical papers on organizational learning in broader public contexts (e.g., schools, municipalities), which excluded 181 articles. This second exclusion criterion was used because the activities in these contexts are different from those of the mainstream public organizations. The remaining twelve papers met the inclusion criteria, which were empirical research on organizational learning in public sector organizations.

\subsection{Procedure for analysis of papers}

We selected the following information from each paper: name of the author(s), year of publication, title, journal, study goal, keywords, definition of OL, participants or sample, dependent and independent variables, method of data collection, analysis, and results.

\section{RESULTS}

The twelve papers of this review were published in 11 journals, written by 28 authors affiliated to 18 institutions, located in 12 countries. We highlight that four researchers have links with two institutions located in different countries.

The journals with the largest number of empirical papers were The Learning Organization and International Journal of Public Administration, both with two publications on this topic (Table 02).

\begin{tabular}{lc}
\hline \multicolumn{1}{c}{ Journals } & Number of articles \\
\hline Environmental Management & 1 \\
International J ournal of Public Administration & 2 \\
International J ournal of Public Sector Performance & 1 \\
Management & 1 \\
Journal of Contingencies and Crisis Management & 1 \\
Journal of Quality & 1 \\
Journal of Strategic Information Systems & \\
\hline
\end{tabular}




\begin{tabular}{ll}
\hline Management Learning & 1 \\
Public Administration Review & 1 \\
Revista de Administração Pública & 1 \\
The Learning Organization & 2 \\
\hline
\end{tabular}

Table 02. Journals and the respective number of published papers

Search: Authors (2018)

The countries with more empirical publications on the topic were Netherlands, Brazil and Sweden, both with two publications (Table 03).

\begin{tabular}{lcc}
\hline \multicolumn{1}{c}{ Country } & Number of institutions & Number of papers \\
\hline UK & 1 & 1 \\
Thailand & 1 & 1 \\
Israel & 3 & 1 \\
Netherlands & 2 & 2 \\
Brazil & 2 & 2 \\
Sweden & 2 & 2 \\
Singapore & 1 & 1 \\
Canada & 1 & 1 \\
Taiwan & 1 & 1 \\
Finland & 1 & 1 \\
Belgium & 1 & 1 \\
\hline
\end{tabular}

Table 03 . Country, the respective number of institutions and published papers Search: Authors (2018)

These papers were published from 1999 to 2017 (Figure 01). In 1999, only one paper was published. The years with the largest number of empirical papers were 2011, 2012 and 2015.

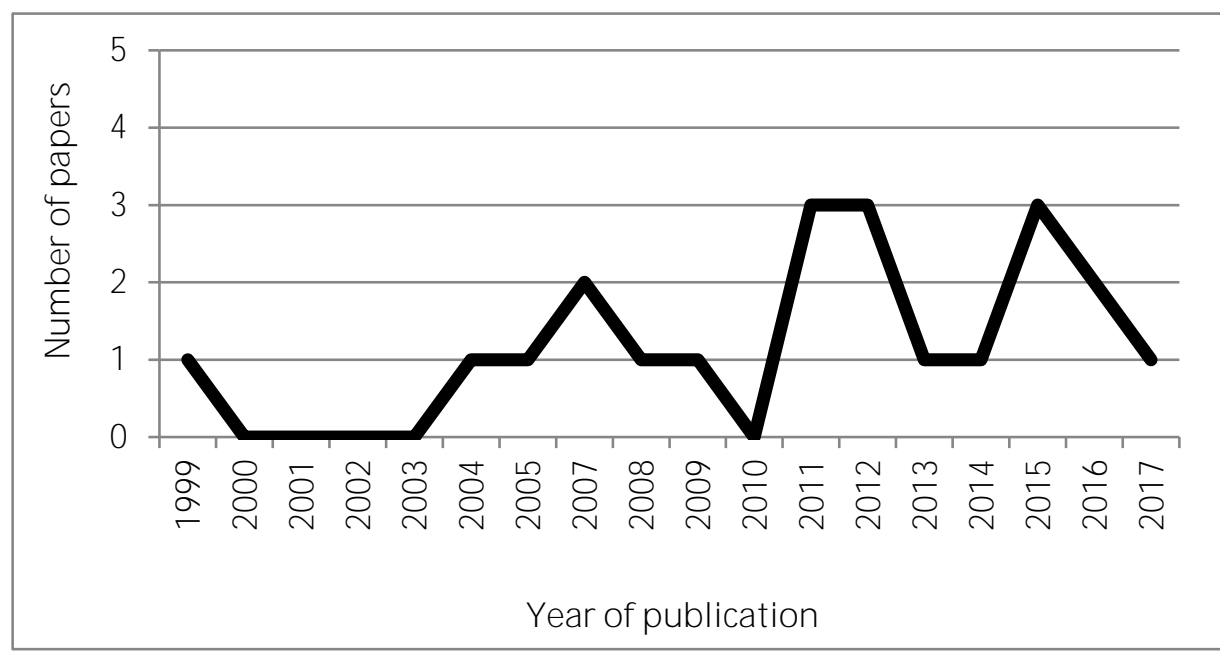

Figure 01. Empirical publications on organizational learning in public organizations Search: Authors (2018)

With respect to papers published recently (2015 and 2017), in 2015 three papers were published, and in 2016 and in 2017 we identified only one article per year, showing that there is still a small number of empirical papers on the subject. In the following section we synthesize the papers on organizational learning in the public sector. 


\section{Description of the empirical papers}

The studies were cross-sectional. Ten of the twelve papers are qualitative with predominance in health and education setting. We describe each study below, highlighting its objectives, research context, and results.

Vince and Saleem (2004) conducted a study with nine managers of a UK public organization to examine the perceived relationship between emotion, learning and organizing. According to the managers, the dynamics resulting from repeated patterns of blame and caution interfere in communication and reflection processes in the organization. This also affects negatively the implementation of organizational learning strategies.

Yeo (2007) investigated OL and its impacts on public organizations from various sectors (health, education and manufacturing) in Singapore. The study found that commitment of managers was a catalyst of OL. Yeo (2007) also found that facilitators of OL (open communication, reward and compensation) are related to workers' well-being. According to the author, the investigated public organizations showed more concern with the cognitive and behavioral development of their employees than with financial results.

Based on the analysis of a change process resulted from the implementation of an information system (IS) in Singapore's national library, Phang et al. (2008) developed a study to understand the perceived relationships between the organizational elements (learning, culture, memory and organizational policies) and OL success. According to the top managers, institutional environment interfered in internal processes in the organization that, in turn interfered in the OL process. According to the managers, such relationship resulted from the improved efficiency of the organization as a whole in the development and evaluation of their human resources via IS.

Lundberg (2011) analyzed the environmental evaluation process of a Swedish public institution to understand how follow-up can be used as an organizational learning tool. Results revealed that by monitoring actual and unforeseen impacts on the environment and by using such information for $\mathrm{OL}$, the actions and procedures of the studied organization can be strategically and continuously improved.

Based on the analysis of debriefing documents produced in a public medical center in Israel, Holzmann et al. (2012) found a link between experience and management of future occurrences. Results showed that poor communication, documentation and information exchange between managers and the stakeholders accounted for most of the undesired occurrences and for the inefficiency of the OL processes in the investigated organization.

The study conducted by Yip-So (2012) analyzed learning roles based on a comparative study with different public organizations in Taiwan. In-depth interviews were conducted with 24 top managers of the studied organizations. As a result, two kinds of learning were identified: political learning and instrumental learning. The first type was described as a process limited to the central decision-making body and is related to the identification of indicators and goals, and formulation of policies. Example of this process includes the supply of customized services in response to community demands. The second type of learning was described as a single loop learning process of improvement of routines to achieve organizational goals.

Bertolin et al. (2013) developed a study to understand OL in the public service based on social elements involved in working practices (e.g., integration, informality, autonomy, flexibility, participation, reflexivity, and sharing of practices and experiences). Through observation and interviews with sectoral managers of a Brazilian public health organization, the authors found that learning is still quite distant from the management practices due to the predominance of bureaucratic and centralized practices. The authors concluded that these elements inhibit streamlined management, the organization of daily activities, and learning in the public sector.

Santos and Steil (2015) developed a study on OL processes during the adoption and use of an information system (IS) in a Brazilian public university. Documents were analyzed and 22 individuals were interviewed, including the president, vice-president, professors and civil servants of the university. The study demonstrated that social and cognitive processes of individual and group learning were associated with specific modes of power, especially discipline, influence, force, and domination. In addition, only when a 
specific configuration of these power modes occurred, adoption and use of an information system were possible in the university.

By analyzing a change caused by the implementation of a budget cutting policy in a Finnish public hospital, Mutiganda (2016) identified facilitators of learning and change. These are power delegation, positive managerial coaching, active communication between managers, freedom for managers to set priorities in the redesign process, specification of budgetary responsibilities of each manager, and use of a schedule to monitor clinic performance. The institutionalization of said change was achieved using the managers' power and the managerial diagnosis systems used to monitor the implementation of the management goals.

In a recent study, Broekema et al. (2017) identified the factors that interfered in the OL process based on four veterinary crises (classical swine fever, food-and-mouth disease, avian influenza, and Q fever) in a public organization in the Netherlands. In-depth interviews were conducted with key experts in the organization and documents were analyzed. Considering the analyzed crises, the results showed that OL consisted of a complex process involving factors related to the political-economic context, socio-emotional understanding, organizational culture, organizational structure, crisis management, and organizational loss of memory.

Finally, two papers are quantitative studies, which analyzed the relation between certain variables and $\mathrm{OL}$ in the public sector. Barette et al. (2012) identified OL facilitators in a research conducted with 2,081 executives from Canadian public organizations. The instrument used had 29 items (Cronbach's alpha: 0.96), with scale ranging from 0 - very difficult for a manager to evaluate or observe; 1 - sometimes possible for a manager to evaluate or observe; and 2 - easy for a manager to evaluate or observe. Five facilitators related to the process (knowledge acquisition and transformation) and to the environment (learning leadership, support to $\mathrm{OL}$, learning culture, and strategic management) were identified. Of the five OL facilitators, knowledge acquisition and transformation was the main predictor of individual learning and organizational performance. Learning leadership and support to organizational learning also predicted individual learning, but to a lesser degree of association. Support to OL also predicted group learning as well as learning culture.

Tang and Yeh (2015) examined the relationship of organizational culture, leadership style and OL in organizational innovation. The study was conducted with 398 employees of Taiwan public organizations. The instrument used is composed of 75 items, with a measuring scale ranging from 1 (disagree strongly) to 5 (agree strongly), duly validated (Cronbach's alpha: $0.726 \sim 0.929$ ). The results showed that organizational culture and organizational learning, mediated by organizational innovation, improved organizational performance.

\section{DISCUSSION}

The aim of this review is to understand what is known about organizational learning in public organizations, based on the analysis of empirical papers on this construct, and identify areas of future studies. From the analysis of the twelve papers, some general considerations about the studies on Organizational Learning developed until 2017 can be established.

The empirical studies developed so far are descriptive and mostly qualitative. The majority of studies on OL was carried out in Europe (six) and Asia (four). Antonello and Gody (2009) identified that only 25\% (23) of the Brazilian organizational learning studies were conducted in public organizations. These results demonstrate that such delimitation of territories for existing studies can restrain the expansion of knowledge and the conduction of comparative studies on the topic of interest (Antonello and Godoy, 2009).

The analyzed studies define organizational learning as a dynamic and multi-level process involving the understanding of experiences and the generation of new knowledge. It is a process (Holzmann et al., 2012) that facilitates the "evolution of organizational knowledge and practices" (Barette et al., 2012, p. 138) and helps the adaptation to changes in the public organizational setting (Crossan et al., 1999). As a process, organizational learning is incorporated into the culture and routines of an organization (Voronov and Yorks, 2005). Some studies identified OL facilitators or inhibitors in public organizations but they are still poorly understood (Antonello and Godoy, 2009, 2010).

As regards the processes and models of organizational learning, some studies used the 4ls model proposed by Crossan et al. (1999) and the framework of Lawrence et al. (2005) to analyze the OL process 
in public organizations. We also identified the prevalence of single loop learning proposed by Argyris and Schon (1978). Finally, we point out that some studies have investigated factors that foster or inhibit OL in public organizations.

Bureaucracy and centralized management are the main characteristics found in the studies. The results of the studies show prevalence of single loop learning (Argyris and Schon, 1978) in public organizations. Often, the public sector is considered resistant to double loop learning due to the influence of its bureaucracy and strong departmental cultures. Double loop learning questions why things are done (Common, 2004), and is present in more complex and nonprogrammable activities (Bennet and Bennet, 2006). On the other hand, single loop learning is more visible in the public sector, since it consists of a process that simply questions how the same things can be done in a better way (Common, 2004). Public organizations are subject to high levels of supervision, accountability and formal political control (Hartley and Skelcher, 2008). The single loop learning is considered suitable to this kind of context due to recurrent problems and programmable routines that exist in this environment (Bennet and Bennet, 2006).

Some studies (Mutiganda, 2016; Santos and Steil, 2015) used the 4ls model (Crossan et al., 1999) and the framework of Lawrence et al. (2005) to analyze the OL process in public organizations. These studies identified a link between political aspects, different forms of power and OL. The forms of power can enable or block up the access to learning practices and provide facilitating means for OL (Contu and Wilmott, 2003). Researchers (Easterby-Smith, 1997; Contu and Willmott, 2003; Ferdinand, 2004) encourage future studies on the power relations that permeate AO processes. Domination and force, for instance, can facilitate or hinder the processes of participation of stakeholders, development of competencies and formulation of strategies (Voronov and Yorks, 2005). Literature underlines the role the 4ls to identify barriers to the organizational learning process either by theoretical or practical questions (Schilling and Kluge, 2009). In the literature review that Rashman et al. (2009) carried out on OL and knowledge in public organizations, they identified that "organizational learning is an inherently political process, and both formal and informal politics can support and/or undermine learning efforts" (Rashman et al., 2009, p. 485). Although still little explored in studies on OL, power dynamics are considered important elements to understand $\mathrm{OL}$ and knowledge in public organizations (Rashman et al., 2009). On the one hand, power dynamics based on formal authority can foster the learning processes in public organizations because they provide stability and continuity (Lawrence et al., 2005). On the other hand, there may be resistance from members of the organization to strive for the organization to learn, because they understand that $\mathrm{OL}$ is not in line with their professions (Greiling and Halachmi, 2013). To advance in the understanding of this relationship, researchers encourage further studies to investigate the dynamics of power involved in OL processes (Contu and Willmott, 2003; Ferdinand, 2004; Rashman et al., 2009).

Empirical evidences found a relationship between $\mathrm{OL}$ and organizational performance in the public sector. Barette et al. (2012) identified OL facilitators for environmental situations and processes that influence $\mathrm{OL}$. These facilitators predict individual and group learning. Knowledge acquisition and transformation was the OL facilitator that showed a positive relationship with organizational performance (Barette et al., 2012). Empirical evidences (Cavaleri et al., 2007; Monavvarian and Kasaei, 2007; Fugate et al., 2009; Olejnicczak, 2014) have shown that "OL improves the performance of an organization both in its strategic and operational activities" (Olejniczak, 2014, p. 15). By means of learning, "the organizations can enhance and strengthen their knowledge and skills" (You et al., 2017, p. 312). The study of Barette et al. (2012) is relevant because it links OL with the performance of public organizations. The relationship between these constructs has a research tradition in private organizations with outcomes that are not always convergent (Bontis et al., 2002; SantosVijande et al., 2005; Panayides, 2007; Dimovski et al., 2008). Advances in understanding this relationship in the context of public organizations are considered complex due to the challenges of measuring a process construct in organizations whose structure and processes are strongly influenced by political and economic factors.

Other environmental-related $\mathrm{OL}$ constructs are predicted by factors that foster or inhibit $\mathrm{OL}$ and personal development in the workplace. A learning-driven organizational culture recognizes the need for individuals to be motivated to create, share and explore knowledge in their organization (Dixon, 1994). These processes are associated with the idea of continuous improvement by identifying, implementing and 
institutionalizing ongoing improvements in the organization (Swart and Kinnie, 2010). This is particularly helpful in public organizations because they have been pressured to learn and improve continuously its processes and services (Hartley, 2008) to increase their value for so ciety (Hartley and Skelcher, 2008; Olejniczak, 2014).

\section{FINAL CONSIDERATIONS}

Learning has become an important concept to understand how organizations evolve over time and adapt to changes that occur in their internal and external environments. This review synthesized the results of empirical studies published until 2017 on OL in public organizations. The evidences show that this topic is still poorly explored. Most of the studies have a qualitative design and seek to identify OL facilitators and inhibitors in public organizations.

Public organizations seek to improve their processes and services and, in doing so, they create value for society; therefore, by identifying and knowing the OL elements (facilitators and inhibitors) public organizations can achieve this goal. The results show that little is known about OL in public organizations. Since the studies were mostly qualitative and descriptive, it is not possible to generalize most of the results to public organizations in a specific region. Due to this aspect, future research studies can investigate the same constructs in different regions and countries. As a result, it is possible to build a base of knowledge capable of identifying common elements in this specific type of organization.

Another possibility for future studies consists of identifying the $\mathrm{OL}$ antecedents and consequences in the public sector, based on the degree of association of the elements identified in the qualitative studies examined in this literature review (Jang, 2010). It is also suggested to conduct studies with larger samples of organizations, so that the results found can be generalized, and OL in the public context in a larger number and more diversified public organizations can be understood more comprehensively.

\section{ACKNOWLEDGEMENTS}

This study was financed in part by the Coordenação de Aperfeiçoamento de Pessoal de Nível Superior - Brasil (CAPES) - Finance Code 001.

\section{REFERENCES}

Abel, M. H. (2015). Knowledge map-based web platform to facilitate organizational learning return of experiences. Computers in Human Behavior, Vol. 51, pp. 960-966. doi:10.1016/j.chb.2014.10.012

Angeloni, M. T. and Steil, A. V. (2011). Alinhamento de estratégias, aprendizagem e conhecimento organizacional. In Tarapanoff, K. Aprendizado organizacional: fundamentos e abordagens multidisciplinares. Curitiba: IBPEX.

Antal, A., Dierkes, M., Child, J . and Nonaka, I. (2003). Organizational learning and knowledge: reflections on the dynamics of the field and challenges for the future. In Dierkes, M., Antal, A., Child, J. and Nonaka, I. (Org.). Handbook of organizational learning and knowledge, Oxford: Oxford University Press.

Antonello, C. S. and Godoy, A. S. (2009). Uma agenda brasileira para os estudos em Aprendizagem organizacional. Revista de Administração de Empresas (RAE), Vol. 49, №. 3, pp. 266-281.

Antonello, C. S. and Godoy, A. S. (2010). A Encruzilhada da Aprendizagem Organizacional: uma Visão Multiparadigmática. Revista de Administração Contemporânea, Vol. 14, No. 2, pp. 310-332.

Avnet, M. S. (2015). A network-based approach to organizational culture and learning in system safety. Procedia Computer Science, Vol. 44, pp. 588-598. doi:10.1016/j.procs.2015.03.061

Argyris, C. and Schön, D. A. (1978). Organizational Learning. A Theory of Action Perspective. Reading Addison Wesley.

Bapuji, H. and Crossan, M. (2004). From questions to answers: reviewing organizational learning research. Management Learning, Vol. 35, No. 4, pp. 397-417.

Barette, J., Lemyre, L., Corneil, W. and Beauregard, N. (2012). Organizational Learning Facilitators in the Canadian Public Sector. International Journal of Public Administration, Vol. 35, pp. 137-149. 
Bastiani, S. N. A. C., Dias, T., Sehnem, S. and Puffal, D. (2015). Limites e possibilidades da inovação como estratégia em organizações públicas. Contextus - Revista Contemporânea de Economia e Gestão, Vol. 13, No. 3.

Bennet, A. and Bennet, D. (2006). The learning organization: Learning as associative patterning", The Journal of Information and Knowledge Management Systems. Vol. 36, No. 4, pp. 371-376.

Bertolin, R. V., Zwick, E. and Brito, M. J. (2013). Aprendizagem organizacional socioprática no serviço público: um estudo de caso interpretativo. Revista de Administração Pública, Vol. 47, No. 2, pp. 493-513.

Bontis, N., Crossan, M. M. and Hulland, J. (2002). Managing an organizational learning system by aligning stocks and flows. Journal of Management Studies, 39, No. 4, pp. 437-469.

Broekema, W., van Kleef, D. and Steen, T. (2017). What factors drive organizational learning from crisis? Insights from the Dutch food safety services' response to four veterinary crises. Journal of Contingencies and Crisis Management, Vol. 25, No. 4.

Cavaleri, S. A., Seivert, S. and Lee, L. W. (2007). Knowledge leadership: The art and science of the knowledgebased organization. Knowledge Management Research and Practice, Vol. 5, pp. 154-156.

Common, R. (2004). Organisational learning in a political environment: Improving policy-making in UK government. Policy Studies, Vol. 25, No. 1, pp. 36-49.

Contu, A. and Willmott, H. (2003). Re-embedding situatedness: The importance of power relations in learning theory. Organization Science, Vol. 14, No. 3, pp. 283-296.

Cooper, H. M. (1982). Scientific guidelines for conducting integrative research reviews. Review of Educational Research, Vol. 52, No. 2, pp. 291-302.

Crossan, M., Lane, H. W. and White, R. E. (1999). An organizational learning framework: from intuition to institution. The Academy of Management Review, Vol. 24, No. 3, pp. 522-537.

Crossan, M., Maurer, C. C. and White, R. (2011). Reflections on the 2009 AMR decade award: do we have a theory of organizational learning?. Academy of Management Review, Vol. 36, No. 3, pp. 446-460.

Dimovski, V., Škerlavaj, M., Kimman, M. and Hernaus, T. (2008). Comparative analysis of the organizational learning process in Slovenia, Croatia, and Malaysia. Expert Systems with Applications, Vol. 34, No. 4, pp. 3063-3070.

Dixon, N. M. (1994). The Organizational Learning Cycle: How We can Learn Collectively. New York: McGrawHill.

Easterby-Smith, M. (1997). Disciplines of organizational learning: contributions and critiques. Human Relations, Vol. 50, No. 9, pp. 1085-113.

Easterby-Smith, M. and Lyles, M. (2011). The evolving field of organizational learning and knowledge management. In Easterby-Smith, M. and Lyles, M. (Ed.), Handbook of Organizational Learning and Knowledge Management. Chippenham: Wiley.

Edmondson, A. C., Dillon, J. R. and Roloff, K. S. (2007). Three perspectives on team learning. The Academy of Management Annals, Vol. 1, No. 1, pp. 269-314.

Ferdinand, J. (2004). Power, politics and state intervention in organizational learning. Management Learning, Vol. 35, No. 4, pp.435-451.

Ferreira, S. A. and Medeiros, A. L. (2012). Será uma comunidade de prática? Um estudo de caso sobre o processo de aprendizagem da diretoria de tecnologia da informação de uma Universidade Federal da região norte do Brasil. Administração Pública e Gestão Social (APGS), Vol. 3, No. 3, pp. 279-299.

Fugate, B. S., Stank, T. P. and Mentzer, J. T. (2009). Linking improved knowledge management to operational and organizational performance. Journal of Operations Management, Vol. 27, No. 3, pp. 247-264.

Gilardi, F. and Radaelli, C. M. (2012). Governance and learning. In Levi-Faur, D. (ed.), Handbook of Governance, Oxford University Press, Oxford, pp. 155-168.

Greiling, D. and Halachmi, A. (2013). Accountability and Organizational Learning in the Public Sector. Public Performance and Management Review, Vol. 36, No. 3, pp. 380-406.

Hartley, J. (2008). The innovation landscape for public service organizations. In Hartley, J., Skelcher, C., Donaldson, C. and Wallace, M. (Eds.). Managing to Improve Public Services. Cambridge: Cambridge University Press.

Hartley, J. C. and Skelcher, C. (2008). The agenda for public service improvement. In Hartley, J., Skelcher, C., Donaldson, C. and Wallace, M. (Eds.). Managing to improve public service, Cambridge: Cambridge University Press.

Holzmann, V., Mischari, S., Goldberg, S. and Ziv, A. (2012). New tools for learning: a case of organizational problem analysis derived from debriefing records in a medical Center. The Learning Organization, Vol. 19, No. 2, pp. 148-162. 
Jang, H. (2010). Examining Organization Learning in Public Sector Organizations: From the Perspective of Florida Municipal Governments. Dissertation (Doctor of Philosophy), The Florida State University, College of Social Sciences and Public Policy.

Jensen, P. E. (2005). A contextual theory of learning and the learning organization. Knowledge and Process Management, Vol. 12, No. 1, pp. 53-64.

Kasemsap, K. (2017). Organizational Learning: Advanced Issues and Trends. In IGI Global, Organizational Learning, pp. 42 - 66, Copyright, IGI Global. doi: DOI: 10.4018/978-1-5225-1642-2.ch003

Lawrence, T. B., Mauws, M. K., Dyck, B. and Kleysen, R. F. (2005). The politics of organizational learning: Integrating power into the 4 I framework. Academy of Management Review, Vol. 30, No. 1, pp. 180-191.

Loiola, E. and Bastos, A. V. B. (2003). A Produção Acadêmica sobre Aprendizagem Organizacional no Brasil. Revista de Administração Contemporânea, Vol. 7, No. 3, pp. 181-201.

Lundberg, K. (2011). A System Thinking Approach to Environmental Follow-Up in a Swedish Central Public Authority: Hindrances and Possibilities for Learning from Experience. Environmental Management, Vol. 48, pp. 23-133.

Lyles, M. and Easterby-Smith, M. (2003). Organizational learning and knowledge management: agendas for future research. In Easterby-Smith, M. and Lyles, M. A. (Org.), Handbook of organizational learning and knowledge management. Oxford: Blackwell.

Maden, C. (2012). Transforming public organizations into learning organizations: a conceptual model. Public Organization Review, Vol. 12, No. 1, pp. 71-84.

Magalhães, R. (1998). Organizational Knowledge and Learning. In Von Krogh, G., Roos, J . and Kleine, D. (Eds.). Knowing Firms - Understanding, Managing and Measuring Knowledge. London: Sage Publications.

Mahler, J. G. and Casamayou, M. H. (2009). Organizational Learning at NASA: The Challenger and Columbia Accidents. Washington, DC: Georgetown University Press.

Merad, M., Dechy, N. and Marcel, F. (2014). A pragmatic way of achieving highly sustainable organisation: Governance and organisational learning in action in the public French sector. Safety Science, Vol. 69,pp. 18-28. doi:10.1016/j.ssci.2014.01.002

Monavvarian, A. and Kasaei, M. (2007). A KM model for public administration: The case of Labour Ministry. The Journal of Information and Knowledge Management Systems, Vol. 37, No. 3, pp. 348-367.

Moreno-Luzon, M. D. and Lloria, M. B. (2008). The role of non-structural and informal mechanisms of integration and coordination as forces in knowledge creation. British Journal of Management, Vol. 19, No. 3, pp. 250-276. doi:10.1111/j.1467-8551.2007.00544.x

Moynihan, D. P. and Landuyt, N. (2009). How do public organizations learn? Bridging cultural and structural perspectives. Public Administration Review, Vol. 69, No. 6, pp. 1097-1105.

Mutiganda, J. C. (2016). Financial management of public services in a hybrid organisation: a learning approach in inter-organisational settings. International Journal of Public Sector Performance Management, Vol. 2, No. 4.

Naghi, A. A., Gholamrez, J., Mehdi, A. S., Reza, H. and Majid, R. (2010). Increasing the intellectual capital in organization: Examining the role of organizational learning. European Journal of Social Sciences, Vol. 14, No. 1/2, pp. 98-112.

Olejarski, A. M. O., Potter, M. and Morrison, R. L. (2018). Organizational Learning in the Public Sector: Culture, Politics, and Performance", Public Integrity, pp. 1-17. doi: 10.1080/10999922.2018.1445411

Olejniczak, K. (2014). Why learning matters. In Olejniczak, K. and Mazur, S. (Eds.). Organizational learning: A Framework for Public Administration. Warsaw: Scholar Publishing House.

Panayides, P. M. (2007). The impact of organizational learning on relationship orientation, logistics service effectiveness and performance. Industrial Marketing Management, Vol. 36, No. 1, pp. 68-80.

Picoli, F. R. and Takahashi, A. (2016). Capacidade de Absorção, Aprendizagem Organizacional e Mecanismos de Integração Social. Revista de Administração Contemporânea, pp. 01-20.

Phang, C. W., Kankanhalli, A. and Ang, C. (2008). Investigating organizational learning in eGovernment projects: A multi-theoretic approach. Journal of Strategic Information Systems, Vol. 17, pp. 99-112.

Rashman, L., Withers, E. and Hartley, J. (2009). Organizational learning and knowledge in public service organizations: A systematic review of the literature. International Journal of Management Reviews, Vol. 11 , No. 4, pp. 463-494.

Rodríguez, O. (2005). Guías de apoyo a localidad de la gestión pública local, Guía 3, La gestión del conocimiento al servicio de la mejora continua de las administraciones locales. Madrid: Ministerio de Administraciones Públicas.

Salim, I. and Sulaiman, M. (2011). Organizational learning, innovation and performance: A study of Malaysian small and medium sized enterprises. International Journal of Business and Management, Vol. 6, No. 12, pp. 118-126. doi:10.5539/ijbm.v6n12p118 
Santos, N. (2014). Organizational learning and Web 2.0 technologies: Improving the planning and organization of a software development process. In Cruz-Cunha, M., Moreira, F. and Varajao, J. (Eds.). Handbook of research on enterprise 2.0: Technological, social, and organizational dimensions, pp. 512 528, Hershey, PA: IGI Global. doi:10.4018/978-1-4666-4373-4.ch027

Santos, J. L. S. and Steil, A. V. (2015). Organizational learning and power dynamics: a study in a Brazilian University. The Learning Organization, Vol. 22, No. 2, pp. 115-130.

Santos, J. L. S., Martins, P. P. and Steil, A. V. (2015). Aprendizaje y Memoria Organizacional. ¿Cuáles el perfil de la producción científica internacional y qué se ha investigado en las organizaciones públicas?. Documentos y Aportes en Administración Pública y Gestión Estatal- DAAPGE, Vol. 25, pp. 7-30.

Santos-Vijande, M. L., Sanzo-Pérez; M. J., Álvarez-González, L. I. and Vázquez-Casielles, R. (2005). Organizational learning and marketing orientation: interface and effects on performance. Industrial Marketing Management, Vol. 34, pp. 87-202.

Schilling, J and Kluge, A. (2009). Barriers to organizational learning: An integration of theory and research. International Journal of Management Reviews, Vol. 11, No. 3, pp. 337-360.

Swart, J . and Kinnie, N. (2010). Organizational learning, knowledge assets and HR practices in professional service firms. Human Resource Management Journal, Vol. 20, No. 1, pp. 64-79.

Tang, L. and Yeh, Y. (2015). Effect of Organizational Culture, Leadership Style, and Organizational Learning on Organizational Innovation in the Public Sector. Journal of Quality, Vol. 22, No. 5.

Torraco, R. J . (2005). Writing Integrative Literature Reviews: Guidelines and Examples. Human Resource Development Review, Vol. 4, No. 3, pp. 356-367.

Vera, D. and Crossan, M. (2005). Organizational learning and knowledge management: toward an integrative framework. In Easterby-Smith, M. and Lyles, M. A. (Eds.). Handbook of organizational learning and knowledge management, Madden: Wiley-Backwell.

Vince, R. and Saleem, T. (2004). The Impact of Caution and Blame on Organizational Learning. Management Learning, Vol. 35, No. 2, pp. 133-154.

Voronov, M. and Yorks, L. (2005). Taking power seriously in strategic organizational learning. The Learning Organization, Vol. 12, No. 1, pp. 9-25.

Whee, T. T. G., Ngah, R. and Seng, Y. C. (2012). The Relationship of Knowledge Management Capabilities, Learning Organization and Organizational Performance in Public Sector of Dubai Government. Knowledge Management International Conference (KM/Ce), J ohor Bahru, Malaysia.

Woszezenki, C. R., Besen, F., Santos, J. L. and Steil, A. V. (2012). Mapeamento das Publicações AcadêmicoCientíficas sobre Desaprendizagem Organizacional", 23ㅇsimpósio Brasileiro de Informática na Educação - SBIE, Rio de Janeiro.

Yeo, R. K. (2007). Organizational learning in representative Singapore public organizations. International Journal of Public Sector Management, Vol. 20, No. 5, pp. 345-365.

Yip-So, B. W. (2012). Learning as a Key to Citizen-centred Performance Improvement: A Comparison between the Health Service Centre and the Household Registration Office in Taipei City. The Australian Journal of Public Administration, Vol. 71, No. 2, pp. 201-210.

You, J., Kim, J . and Lim, D. H. (2017). Organizational Learning and Change: Strategic Interventions to Deal with Resistance. Handbook of Research on Human Resources Strategies for the New Millennial Workforce, Copyright - IGI Global, pp. 310 -328. 